\title{
EVALUATION OF THE POTENTIAL OF SEED RAIN AS AN ALTERNATIVE FOR FOREST RESTORATION IN PERMANENT PRESERVATION AREAS ${ }^{1}$
}

Emerson Pereira da Silva ${ }^{2 *}$, Fabricio Gomes Figueiredo ${ }^{3}$, Shaline Séfara Lopes Fernandes ${ }^{4}$ e Zefa Valdivina Pereira $^{5}$

\footnotetext{
${ }^{1}$ Recebido em 17.09.2014 aceito para publicação em 20.11.2015.

${ }^{2}$ Universidade Federal da Grande Dourados, UFGD, Programa de Pós-Graduação em Bioprospecção, Dourados, MS - Brasil. E-mail:<emersonsilva@ufgd.edu.br>.

${ }^{3}$ Universidade Federal da Grande Dourados, UFGD, Programa de Pós-Graduação em Ciência e Tecnologia Ambiental, Dourados, MS - Brasil. E-mail: <figueiredofabricio@hotmail.com>.

${ }^{4}$ Universidade Estadual de Mato Grosso do Sul, UEMS, Programa de Pós-graduação em Recursos Naturais, Dourados, MS - Brasil. E-mail: <shaline_sefara@hotmail.com>.

${ }^{5}$ Universidade Federal da Grande Dourados, Faculdade de Ciências Biológicas e Ambientais, Dourados, MS - Brasil. E-mail: <zefapereira@ufgd.edu.br>.

*Autor para correspondência.
}

\begin{abstract}
The ecological restoration of degraded areas using seeds collected in forest remnants has shown significant results. This study was developed to verify the potential of seed rain to regenerate forest fragments of a Permanent Preservation Area (PPA) in the Apa River Basin which is located in the southwestern portion of the Mato Grosso do Sul state, Brazil. To develop the study, we installed 25 collectors measuring $1 \mathrm{~m}^{2}$ each, which were systematically distributed on an area of $1.5 \mathrm{ha}$. Seed gathering was conducted in a monthly basis throughout the year of 2013. A total of 26.411 propagules were identified and distributed among 50 species, 45 genera and 32 families. In terms of the propagules distribution, $70.51 \%$ were identified as trees, $22.8 \%$ as lianas, $6.5 \%$ as shrubs, 0.1 as herbaceous, $0.05 \%$ as palm and $0.05 \%$ could not be classified. The value for the Shannon Diversity Index was $\left(\mathrm{H}^{\prime}\right)=1.67$ and the Pielou Evenness index was $(\mathrm{J})=0.42$. These results indicate that the seeds rain has low species diversity with the abundance of a few species. The overall results suggest that seed rain can be a potential technique for restoration of the PPAs and other forested areas. However, it is necessary to enhance the diversity of tree species.
\end{abstract}

Keywords: Restoration; Riparian forest; Seed rain.

\section{AVALIAÇÃO DO POTENCIAL DA CHUVA DE SEMENTES COMO ALTERNATIVA PARA RESTAURAÇÃO FLORESTAL EM ÁREAS DE PRESERVAÇÃO PERMANENTE}

RESUMO - A restauração ecológica de áreas degradadas, a partir da chuva de sementes coletadas em remanescentes florestais, tem mostrado resultados muito significativos. Este estudo foi desenvolvido com o objetivo de conhecer o potencial da chuva de sementes de uma Área de Preservação Permanente (APP) do Rio Apa, localizado na região Sudoeste do Estado de Mato Grosso do Sul, Município de Ponta Porã. Foram instalados 25 coletores, medindo $1 \mathrm{~m}^{2}$ cada um, distribuidos de forma sistemática em uma área de 1,5 ha. As coletas foram realizadas mensalmente durante o ano 2013. Foram identificados um total de 26.411 propágulos, distribuidos em 50 espécies, 45 gêneros e 32 famílias. Em termos de distribuição dos propágulos, 70,51\% é do tipo arbóreo, 22,8\% de lianas, 6,5\% de arbustivas, $0,1 \%$ de herbáceas, 0,05\% de palmeiras e 0,05\% não puderam ser classificados. O valor do Índice de Diversidade de Shannon $\left(H^{\prime}\right)$ foi de 1,67 e o índice de Equabilidade de Pielou $\left(J^{\prime}\right)=0,42$. Esse resultado indica que a chuva de sementes tem baixa diversidade de espécies com abundância de algumas espécies. Os 
resultados sugerem que a chuva de sementes apresenta potencial como técnica para restauração de APPs e outras áreas similares da região. No entanto, é necessário aumentar a diversidade de espécies arbóreas.

Palavras-chave: Restauração; Mata ciliar; Chuva de sementes.

\section{INTRODUCTION}

In a forest formation, a primary factor that promotes the occurrence of ecological processes is the production of seeds (initial supply), followed by the arrival of these seeds in the soil, forming a seed bank that, under appropriate conditions, may allow the growth of regenerating species and reach adulthood (HARPER, 1977; WANG; SMITH, 2002). This cycle results in the process of natural regeneration of forest areas, and is strongly related to seed dispersal in forest fragments (HOPFENSPERGER, 2007; BOSSUYT; HONNAY, 2008).

The propagules dynamic dispersion (fruit, seeds and seed heads) of a plant community is the movement of these individuals far from the mother plant (RODRIGUES et al., 2009a). According to Levin et al. (2003), the dispersion can be understood as a unidirectional movement of the organism to a different environment than the one where it was originated. The arrival of these seeds in other environments enables the colonization in of tenisolated sites, representing a perpetuating mechanism of plant populations; allowing the maintenance, and even a change in the environmental composition. The deposition of the seeds far from the mother plant can also allow greater survival of these ones, reducing a future competition between the seedling and the mother plant, favoring its establishment on site and minimizing the chances of predation (JANZEN, 1970; CONNELL, 1971).

The forms of propagule dispersion maybevaried, going through different scattering agents (HOWE; SMALLWOOD, 1982). When the dispersion is performed by animals this mechanism is known as zoochory when it is performed by the own mother plant it is called autochory, and when it's performed by wind, it is called anemochory. In general, there is a predominance of zoochorous dispersal mechanism, in which the seedlings are transported by animals, reaching $90 \%$ in tropical forests (MORELLATO; PIGFILHO, 1992), which highlights its importance. However, the presence of these dispersing elements in an area depends on factors such as year-round food availability, shelter for these animals, and the presence or absence of certain predators on site, such conditions must be guaranteed by restoration projects (RODRIGUES, et al., 2009b).

Some factors such as predation and burial of propagules are cited as obstacles because of interference in the dispersion, which may affect the operation of this mechanism. This limitation in the dispersion syndrome occurs when some mechanism prevents the seed to reach another location with a recruitment potential, and prevents it to be settled (BUENO et al., 2013; MULLER-LANDAU et al., 2002). These ecological filters prevent a propagule pass a phase ahead towards its development as a seedling. This way, not all seeds come to the soil, because propagules are subject to predation and, for example, serve as food for animals (RODRIGUES, 2013).

Dynamic studies of seed rain in forest formations are initial data to support the ecological restoration of degraded areas because they favor the comprehension of the ecological characteristics of the species, as well as, the species dispersion form and seed production (BARBOSA; PIZO, 2006). According to Barbosa (2012), in studies about seed rain in forest remainings, there have been advocated the search for new concepts, methods and techniques to be used in recovery projects in degraded areas, or even in the biodiversity management. Thus, this study aimed to characterize and evaluate the dynamics of seed rain of a Permanent Preservation Area in the headwaters of the Apa River, in Ponta Porã city, MS.

\section{MATERIALAND METHODS}

The Apa River headwaters are located in Ponta Porã, Mato Grosso do Sul, Brazil (22 01 ' 54 ' $\mathrm{S}, 055^{\circ}$ $52^{\prime} 42^{\prime}$ W) within an environmental preservation area established by the decree 4743/2004 (Figure 1). The climate in this region is classified as Cfa (KÖPPEN, 1936), with winter (dry season), corresponding to the months from March to August, while summer (rainy season) runs from September to February (ZAVATINI, 1992). The average annual rainfall for the region is 
$1.395 \mathrm{~mm}$, however, in 2013, the annual rainfall reached $1.731 \mathrm{~mm}$ (INMET, 2013), with an average annual temperature of $21.5^{\circ} \mathrm{C}$ (CLIMA-DATA, 2013). The vegetation of the area is an ecotone between the Brazilian Cerrado and Atlantic Forest, composed by the riverside semidecidual seasonal forest (IBGE, 2004).

The study area is in a landscape dominated by livestock, where it is observed the large presence of grasses (brachiaria) and the discontinuation of the forest fragment. The nearest forest fragments in the area correspond to the headwaters of two rivers, which are 0.8 and $2 \mathrm{~km}$ away from the place of study.

To collect the seed rain 25 seed traps of $1 \mathrm{~m}^{2}$ of iron and with bottom composed by a nylon with fabric screen mesh of $1 \mathrm{~mm}$ by $1 \mathrm{~mm}$ were installed and they were systematically distributed, being 20 meters distant from each other. They were tied on the trees 1 meter above ground level by a nylon rope.

The material was taken from the collectors monthly, between January and December/2013, stored and transported to the Environmental Restoration Laboratory of the Universidade Federal da Grande Dourados. The samples were separated, distinguishing the seeds from other materials (leaves, flowers and branches).

The found seeds were identified with the aid of specialized literature, and comparisons to reference material (seeds collected in the area) were made. Specialists from Universidade Federal da Grande Dourados, Universidade Estadual de Mato Grosso do Suland Universidade Estadual de Campinas were also consulted. The sampled species were classified according to the Angiosperm Phylogeny Group III (APG, 2009).

The dispersion syndrome was determined in: anemochoric, zoochoric, and autochorous dispersions (VAN DER PIJL, 1969). The successional classification in ecological groups was performed according to Gandolfi et al. (1995): as pioneers, early secondaries and late secondaries. The determination of these successional classes was based on specialized bibliographies (COSTA; MANTOVANI, 1995; RONDON-NETO et al., 2000; STRANGHETTI et al., 2003; CATHARINO et al., 2006; GRINGS; BRACK, 2009; GUARATINI etal., 2008; LEITE; RODRIGUES, 2008; FREITAS-JUNIOR et al., 2009; PRADO-JUNIOR et al., 2010; SANTOS et al., 2011; PRADO-JUNIOR et al., 2011) and when there was disagreement on the standings, the agreement of the majority was followed.

The diversity indices Shannon-Wiener $\left(\mathrm{H}^{\circ}\right)$ \& Evenness(J'), (PIELOU, 1975; MAGURRAN, 1988) were calculated with the Fitopac 2 program (SHEPHERD, 2010). The Spearman correlation analysis between precipitation and the monthly richness was held at the BioEstat 5.0 statistical program (AYRES et al., 2000). The total and monthly seed deposition density (seeds $/ \mathrm{m}^{2}$ ), was calculated by dividing the number of seeds by the total sample area (MUELLER-DOMBOIS; ELLENBERG, 1974).

\section{RESULTS}

A total of 26,411 seedlings were collected, which were distributed in 50 species, 45 genera and 32 families, being three seedlings identified only by family.

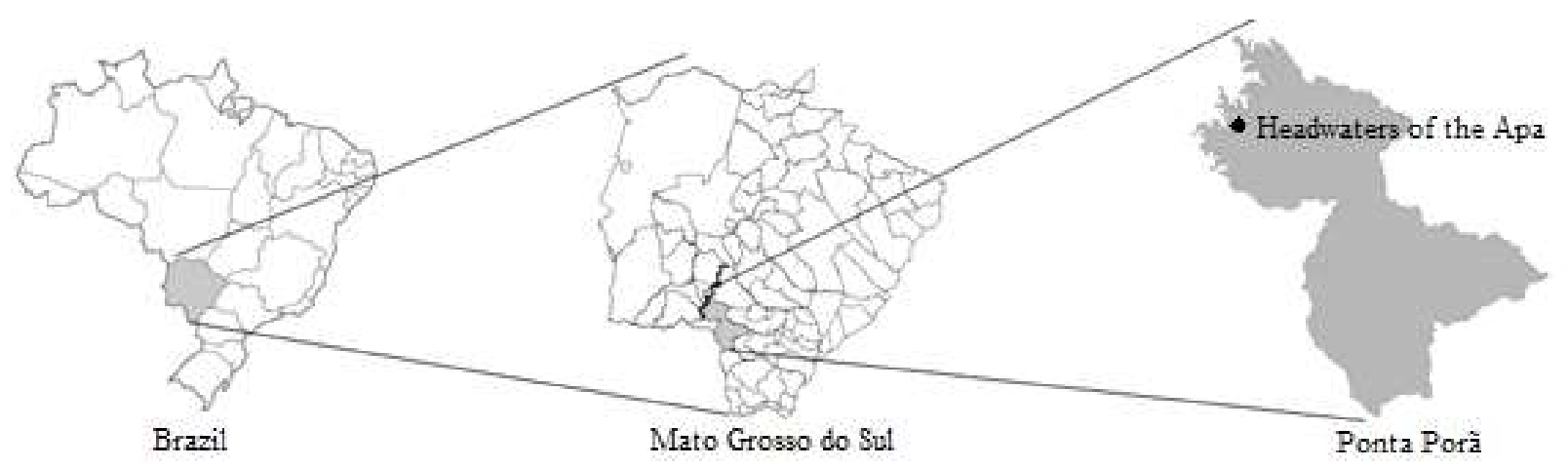

Figure 1- The headwaters location of the Apa River in Ponta Porã, Mato Grosso do Sul, Brazil. Figura 1 - Localização das nascentes do rio Apa, no Municipio de Ponta Porã, Mato Grosso do Sul, Brasil. 
The 13 families with the highest number of species present together 31 species, accounting for $62 \%$ of all species found in this forest fragment. These 31 species were distributed in 27 genera $(60 \%)$, from a total of 45 genera that were identified. Families with larger numbers of species were Sapindaceae (4), Moraceae (3), Lauraceae (3) and Bignoniaceae (3). The remaining families were represented by one or two species.

The composition of species found in seed rain presented a Shannon Weaver diversity index $\left(\mathrm{H}^{\circ}\right)$ of 1.67 and Pielou evenness $\left(\mathrm{J}^{\circ}\right.$ ) of 0.42 . Whilst the Spearman nonparametric test indicated the existence of significant relation between species richness and monthly rainfall, being the Spearman coefficient of 0.77 , and $p$ value of 0.003 .

The peak months with greater deposition of seeds were August, September and October, 13,318 propagules per $\mathrm{m}^{2}(35.5 \%), 3.662$ propagules per $\mathrm{m}^{2}$ $(9.8 \%)$ and 3098 propagules per $\mathrm{m}^{2}(8.3 \%)$ respectively, totaling 20,078 propagules $(53.53 \%)$ from the total of seed rain. This period consists in the end of the dry season and the beginning of the rainy season in the region.

In August 12,524 seeds of a single species were collected, known as fig tree (Ficus guaranitica Chodat), which accounted for $94.0 \%$ of all seedlings collected in this month (Figure 2). Species richness was represented by two distinct peaks during the period of a year, one in March, with 29 species, and the other in October, with 31 species, corresponding, therefore, to the months of greatest botanical diversity in the study period and large volumes of precipitation (Figure 3 ). The annual average richness was 22,33 species. Despite

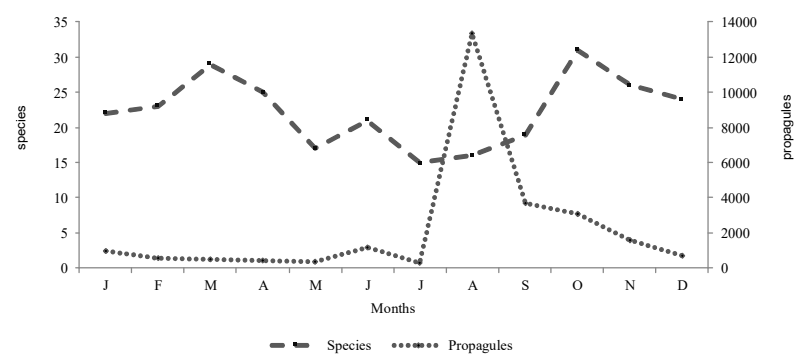

Figure 2 - Total number of species and seedlings found monthly.

Figura 2-Número total de espécies e propágulos encontrados em cada mês.

Revista Árvore, Viçosa-MG, v.40, n.1, p.21-28, 2016 the large amount of collected seedlings, the month of August showed the second lowest richness of species in 2013 and also the period of lower rainfall.

In June, it was observed an increase of propagules, in comparison to previous months, but the peak of this production was in August 2013 with a decrease in the remaining months of the year. The propagules amount increasing observed in June was due to the increased representation by Miconia elegans Cogn (845 individuals).

The species with greater amount of propagules was Ficus guaranitica, with 15,706 individuals, followed by Fridericia florida (DC.), L. G. Lohmann $(3,728)$, and Serjania glabrataKunth $(1,324)$.

Tree species were the most representative in relation to the number of propagules, with 18,623 collected units, followed by lianas (6024), the shrubby forms $(1,711)$, herbaceous (28) and palm trees (13). Twelve seedlings could not be classified due to lack of information (Table 1).

From the 18,623 identified arboreal propagules, 15,706 were just $F$. guaranitica, being $84.3 \%$ of all tree species seedlings found, which characterized the dominance of this species.

Taking the effect of the Ficus guaranitica (outlier) species away from the results, the arboreal species now have 2,917 propagules (27.24\%), lianas have 6,024 (56.27\%), the shrubby forms possess 1,711 (15.98\%), herbaceous have $28(0.26 \%)$, palm trees own $13(0.12 \%)$, and it could not be found any sort of classification for 12 seedlings $(0.11 \%)$.

From the species identified on the headwaters of the Apa River, there was a predominance of early

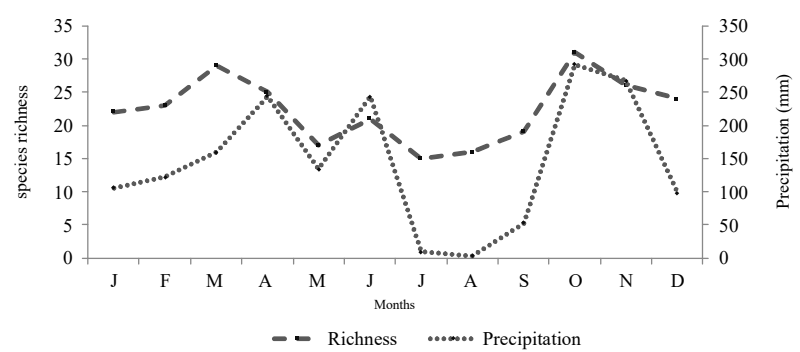

Figure 3 - Precipitation average in the months in 2013 and species richness collected each month.

Figura 3-Médias de precipitação dos meses de 2013 e riqueza de espécies coletadas em cada mês. 
Table 1 - Propagules total and species numbers in quantity and percentage for life forms and successional group found in the surrounding of the headwaters of the Apa River, in Ponta Porã, MS.

Tabela 1 - Total de propágulos e números de espécies, em quantidade e porcentagem para as formas de vida e grupo sucessional encontrados no entorno das nascentes do rio Apa, em Ponta Porã, MS.

\begin{tabular}{|c|c|c|c|c|}
\hline \multirow[t]{2}{*}{ Characteristics } & \multicolumn{2}{|c|}{ Propagules } & \multicolumn{2}{|c|}{ Species } \\
\hline & $\mathrm{N}^{\mathrm{o}}$ & $\%$ & $\mathrm{~N}^{\circ}$ & $\%$ \\
\hline \multicolumn{5}{|l|}{ Life Forms } \\
\hline Arboreal & 18.623 & 70,51 & 26 & 52 \\
\hline Shrubby & 1.711 & 6,48 & 6 & 12 \\
\hline Herbaceous & 28 & 0,10 & 3 & 6 \\
\hline Liana & 6.024 & 22,81 & 10 & 20 \\
\hline Palm tree & 13 & 0,05 & 2 & 4 \\
\hline Not Classified & 12 & 0,05 & 3 & 6 \\
\hline \multicolumn{5}{|c|}{ Successional groups } \\
\hline Pioneer & 844 & 3,20 & 11 & 22 \\
\hline Initial secondary & 18.208 & 68,94 & 12 & 24 \\
\hline Late secondary & 1102 & 4,17 & 11 & 22 \\
\hline Not classified & 6.257 & 23,69 & 16 & 32 \\
\hline
\end{tabular}

secondary, with 12 species (24\%), followed by 11 Pioneer sp. $(22 \%), 11$ late secondary sp. $(22 \%)$, and it was not possible to classify $16 \mathrm{sp}$. $(32 \%)$.

Regarding the dispersion syndrome for species, $70 \%$ are zoochoric. When analyzing the propagules number $(26,411)$, this form of dispersion reaches $75.7 \%$. For other forms of dispersion, the results were $26 \%$ and $23.9 \%$ of anemochoric, and $4 \%$ and $0.4 \%$ for autochorous for the number of species and seedlings, respectively.

\section{DISCUSSION}

The total seed density found in this study was $1,053.5 \mathrm{seed} / \mathrm{m}^{2}$. Values are similar to other studies also carried out in riparian areas, ranging from 288 to $1,804.2$ seeds/m² (MARIMON; FELFILI, 2006; PENHALBER; MANTOVANI, 1997). The total number of collected propagules resembles other previous seed rain researches already made in gallery forests (LAGOS; MARIMON, 2012; VIEIRA; GANDOLFI, 2006), which shows a pattern in seedling numbers from seed rain in these areas, which is responsible for saving about a third of botanical diversity only inthe Brazilian Cerrado (SANO et al., 2008).

Applying the nonparametric Spearman test to check for the existence of any relation on the amount of monthlydeposited propagules with precipitation at the site -it showed a significant relation, besides, it indicated the best time to collect seeds. In the community under study, the preferred time for releasing of seedlings occurred at the end of the dry season, with lower rates of precipitation. These fruit ripening mechanisms according to Rathcke and Lacey (1985) generally coincide with the period that provides the best conditions for successful dispersion and seedling establishment.

The time of greatest richness of species and seedlings is data that enables knowledge of the best time to collect the seed rain for forest restoration purposes; itcan be by direct seeding or seedling production for later planting. Vieira et al. (2001) makes a remark that the time of native seed collection should be as precise as possible, as there are species with short natural longevity and thus the peak of the greatest richiness of species and seedlings establishment could allow viable seeds obtainment on the site.

The low diversity of species and high abundance of some others may be correlated with disturbance occurring in the area, diverging, this way, from what it would be expected for preserved riparian environments, which typically have high biodiversity due to its characteristics (RODRIGUES; SHEPHERD, 2009).

An important element of forest structure, the presence of lianas can represent from $24 \%$ to $40 \%$ of the total flora in tropical forests (GENTRY, 1999). Engel and Fonseca (1998) report that the vines are more abundant in open forests with clearings and disturbed areas. In the surroundings of the head waters of the Apa River, the large presence of liana seedlings is

Revista Árvore, Viçosa-MG, v.40, n.1, p.21-28, 2016 
explained for being an environment highly disturbed by the presence of cattle, and also the presence of a large number of clearings on site. These characteristics support the development of the population of lianas (ENGEL; FONSECA, 1998).

The propagule dispersion syndrome found in the study area is under the influence of the local landscape, because it is a narrow forest fragment and it has a certain degree of forest isolation. These characteristics directly affect the dispersion of seeds, since dispersers have difficulty in foraging isolated areas or areas with degrees of disturbance (UEZU; MATZGER, 2011). In this sense, Rabello et al. (2010), analyzing the influence of the size of forest fragments in seed dispersal, concluded that the potential of the dispersion is qualitatively affected by the fragment size, which influences the foraging of dispersing species.

\section{CONCLUSION}

The area's seed rain in this study has a low biological diversity and high abundance of certain species. However, even with local disturbance, the predominant presence of zoochoric species reflects more favorable conditions for the scatterers' presence in place. Precipitation showed a positive association with the diversity of species and the release of seedlings, with greater dispersion in the dry season. The composing of the seed rain in the surroundings of the headwaters of the Apa River has the potential to be used in the recovery of degraded areas in the region, which could be accomplished through techniques such as tillage and seedling production.

\section{REFERENCES}

\section{ANGIOSPERM PHYLOGENY GROUP III - APG} III. An update of the Angiosperm Phylogeny Group classification for the orders and families of flowering plants: APG III. Botanical

Jounal Linnean Society, v.161, n.20, p.105$121,2009$.

AYRES, M.; AYRES JÚNIOR, M.; AYRES, D.L.; SANTOS, A. S. BioEstat. Versão 5.0. Belém: Sociedade Civil Mamirauá, 2000.

BARBOSA, J.M.; EISENLOHR, P.V.; RODRIGUES, M.A.; BARBOSA, K.C. Ecologia da dispersão de sementes em florestas tropicais. In: MARTINS,

Revista Árvore, Viçosa-MG, v.40, n.1, p.21-28, 2016
S.V. (Ed). Ecologia de florestas tropicais do Brasil. 2. ed. Viçosa, MG: UFV, 2012.

BARBOSA, K. C.; PIZO, M. A. Seed rain and seed limitation in a planted gallery forest in Brazil. Restoration Ecology, v. 14, n.4, p.504-515, 2006.

BOSSUYT, B.; HONNAY, O. Can the seed bank be used for ecological restoration? An overview of seed bank characteristics in European communities. Journal of Vegetation Science, v.19, n.6, p.875-884, 2008.

BUENO, R. S. et al. Functional redundancy and complementarities of seed dispersal by the last neotropical megafrugivores. PLoS ONE, v. 8, n.2, p.56252, 2013.

CATHARINO, E.L.M.; BERNACCI, L.C.; FRANCO, G.A.D.C.; DURIGAN, G.; METZGER, J.P. Aspectos da composição e diversidade do componente arbóreo das florestas da Reserva Florestal do Morro Grande, Cotia, SP. Biota Neotropica, v.6, n.2, 2006.

CLIMA-DATA. Clima: Cabeceira do Apa. Disponível em :http://pt.climate-data.org/location/ 315963/Acessado em: 09 out. 2013.

CONNELL, J. On the role of natural enemies in preventing competitive exclusion in some marine animals and in rain forest trees. In: BOER, P.J.D.; GRADWELl, G.R. (Ed.). Population dynamics. Wageningen, Netherlands: Centre for Agricultural Publishing and Documentation, 1971. p.298-312.

COSTA, L.G.S.; MANTOVANI, W. Dinâmica sucessional da floresta mesófila semidecídua em Piracicaba (SP). Oecologia Brasiliensis, v.1, p.291-305, 1995.

ENGEL, V.L.; FONSECA, R.C.B. Ecologia de lianas e o manejo de fragmentos florestais. Instituto de pesquisas e estudos florestais, v.12, n.32, p.43-64, 1998.

FREITAS JUNIOR, G.; GALLO, Z.; SASSAE, F.C.; CASTRO, M.C.A.A. Levantamento florístico de mata ciliar em áreas de extração de argila no município de São Roque do Canaã-ES. Revista Uniara, v. 12, n.2, 145-156, 2009. 
GANDOLFI, S.; LEITÃO FILHO, H. F.; BEZERRA, C. L. F. Levantamento florístico e caráter sucessional das espécies arbustivo-arbóreas de uma floresta mesófila semidecídua no município de Guarulhos, SP. Revista Brasileira de Biologia, v.55, n.4, p.753-767, 1995.

GENTRY, A.H. Breeding and dispersal systems of lianas. In: GENTRY, A.H.; PUTZ, F.E.; MOONEY, H.A. The biology of vines. Cambridge: Cambridge University Press, 1999. p.393-421.

GRINGS, M.; BRACK, P. Árvores na vegetação nativa de Nova Petrópolis, Rio Grande do Sul. Iheringia, v.64, n.1, p.5-22, 2009.

GUARATINI, M.T.G.; GOMES, E.P.C.; TAMASHIRO, J.Y.; RODRIGUES, R. Composição florística da Reserva Municipal de Santa Genebra, Campinas, SP. Revista Brasileira de Botânica, v.31, n.2, p.323-337, 2008.

HARPER, J.L. The population biology of plants. London: Academic Press, 1977. p. 892.

HOPFENSPERGER, K.N. A review of similarity between seed bank and standing vegetation across ecosystems. Oikos, v.116, n.9, p.14381448,2007

HOWE, H.F.; SMALLWOOD, J. Ecology of seed dispersal. Annual Review of Ecology and Systematics, v.13, p.201-228, 1982.

\section{INSTITUTO BRASILEIRO DE GEOGRAFIA E} ESTATÍSTICA - IBGE. Mapa de biomas do Brasil. Rio de Janeiro: 2004.

\section{INSTITUTO NACIONAL DE METEOROLOGIA -} INMET. Dados de precipitação da estação automática A703. 2013. Disponível em: http://www.inmet.gov.br/ Acessado em: 14 de jan. 2014.

JANZEN, D.H. Herbivores and the number of tree species in tropical forests. The American Naturalist, v.104, n.940, p.501-528, 1970.

KÖPPEN, W. Das geographisca System der Klimate. In: KÖPPEN, W.; GEIGER, G. (Ed.) Handbuch der klimatologie. Gebr.

Borntraeger, v. 1, n.1, p.44, 1936.
LAGOS, M.C.C.; MARIMON, B.S. Chuva de sementes em uma floresta de galeria no Parque do Bacaba, em Nova Xavantina, Mato Grosso, Brasil. Revista Árvore, v.36, n.2, p.311-320, 2012.

LEITE, E.C.; RODRIGUES, R.R. Fitossociologia e caracterização sucessionalde um fragmento de floresta estacional no sudeste do Brasil. Revista Árvore, v.32, n.3, p.583-595, 2008.

LEVIN, S.A.; MULLER-LANDAU, H.C.; NATHAN, R.; CHAVE, J. The ecology and evolution of seed dispersal: a theoretical perspective. Annual Review of Ecology and Systematics, v.34, p.575-604, 2003.

MAGURRAN, A.E. Ecological diversity and its measurement. London: Chapman and Hall, 1988 .

MORELLATO, L.P.C.; LEITÃO-FILHO, H.F. Padrões de frutificação e dispersão na Serra do Japi. In: MORELLATO, L.P.C. (Org.) História natural da Serra do Japi: ecologia e preservação de uma floresta no Sudeste do Brasil. Campinas: Unicamp/Fapesp, 1992. p.112-141.

MARIMON, B.S.; FELFILI, J.M. Chuva de sementes em uma floresta monodominante de Brosimum rubescens Taub. em uma floresta mista adjacente no Vale do Araguaia, MT, Brasil. Acta Botanica Brasilica, v.20, n.2, p.423-432, 2006.

MUELLER DOMBOIS, D.; ELLEMBERG, H. Aims and methods vegetation ecology. New York: Wiley, 1974.

MULLER-LANDAU, H.C.; WRIGHT, S.J.; CALDERON, O.; HUBBELL, S.P.; FOSTER, R.B. Assessing recruitment limitation: concepts, methods and case-studies from a tropical forest. In: LEVEY, D.J.; SILVA, W.R.; GALETTI, M. (Ed.). Seed dispersal and frugivory: ecology, evolution and conservation. Wallingford: 2002. p.35-53.

PENHALBER, E.F.; MANTOVANI, W.M. Floração e chuva de sementes em mata secundária em São Paulo, SP. Revista Brasileira de Botânica, v.20, n.2, p.205-220, 1997.

PIELOU, E.C. Ecological diversity. New York: John Wiley, 1975.

van der PIJL, L. Principles of dispersal in higher plants. Berlin: Springer-Verlag, 1969. 154p.

Revista Árvore, Viçosa-MG, v.40, n.1, p.21-28, 2016

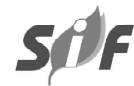


PRADO JÚNIOR, J.A.; LOPES, S.F.; VALE, V.S.; OLIVEIRA, A.P.; GUSSON, A.E.; DIAS NETO, O.C.; SCHIAVINI, I. Estrutura e Caracterização Sucessional da comunidade arbórea de um remanescente de Floresta Estacional Semidecidual, Uberlândia, MG. Caminhos de Geografia, v.12, n.39, p.82-93, 2011.

PRADO JÚNIOR, J.A.; VALE, V.S.; OLIVEIRA, A.P.; GUSSON, A.E.; DIAS NETO, O.C.; LOPES, S.F.; SCHIAVINI, I. Estrutura da comunidade arbórea em um fragmento de floresta estacional semidecidual localizada na reserva legal da Fazenda Irara, Uberlândia, MG. Bioscience Journal, v.26, n.4, p.638-647, 2010.

RABELLO, A.; RAMOS, F.N.; HASUI, E. Efeito do tamanho do fragmento na dispersão de sementes de Copaíba (Copaifera langsdorffii Delf.). Biota Neotropica, v.10, n.1, p.47-54, 2010.

RATHCKE, B.; LACEY, E.P. Phenological patterns of terrestrial plants. Annual Review of Ecology and Systematc, v.16, n.1, p.179-214, 1985.

RODRIGUES, E. Ecologia da restauração. Londrina: Planta, 2013.299p.

RODRIGUES, R.R.; BRANCALION, P.H.; ISERNHAGEN, I. (Org.). Pacto pela restauração da mata atlântica: referencial dos conceitos e ações de restauração florestal. São Paulo:Lerf/Esalq/ Instituto Bioatlântica, 2009a. 264p.

RODRIGUES, R.R.; LIMA, R.A.F.; GANDOLFI, S.; NAVE, A.G. On the restoration of high diversity forests: 30 years of expeciences in the Brazilian Atlantic Forest. Biological Conservation, v.142, p.1242-1251, 2009b.

RODRIGUES, R.R.; SHEPHERD, G.J. Fatores condicionantes da vegetação ciliar. In: RODRIGUES, R. R.; LEITÃO-FILHO, H.F. Matas ciliares: conservação e recuperação. 2. ed. São Paulo: Fapesp, 2009. 320p.

RONDON NETO, R.M.; BOTELHO, S.A.; FONTES, M.A.L.; DAVIDE, A.C.; FARIA. Estrutura e composição florística da comunidade arbustivoarbórea de uma clareira de origem antrópica, em uma floresta estacional semidecídua montana, Lavras, MG, Brasil. Cerne, v.6, n.2, p.79-94, 2000 .

SANO, S.M.; ALMEIDA, S.P.; RIBEIRO, J.F. (Org.). Cerrado: ecologia e flora. Brasília: Embrapa Cerrados, 2008.

SANTOS, M.J.C.; NASCIMENTO, A.V.S.; SILVA, C.E. Caracterização dos remanescentes florestais naturais da zona rural de Guapiara, São Paulo. Natural Resources, v.1, n.1, p.23-36, 2011.

SHEPHERD, G.J. FITOPAC 2. Manual do usuário. Campinas: Departamento de Botânica, Universidade Estadual de Campinas, 2010.

STRANGHETTI, V.; ITURALDE, R.B.; GIMENEZ, L.R.; ALMEIDA, D. Florística de um fragmento florestal do sítio São Pedro, município de Potirendaba, Estado de São Paulo. Acta Scientiarum, v. 25, n. 1, p. 67-172. 2003.

UEZU, A.; METZGER, J.P. Vanishing bird species in the Atlantic Forest: relative importance of landscape conûguration, forest structure and species characteristics.

BiodiverstyConservation, v.20, n.14, p.36273643, 2011.

VIEIRA, A.H.; MARTINS, E.P.; PEQUENO, P.L.L.; LOCATELli, M.; SOUZA, M.G. Técnicas de produção de sementes florestais. Porto Velho: Embrapa-CPAF Rondônia, 2001. 4p. (Circular técnica, 205).

VIEIRA, D.C.M.; GANDOLFI, S. Chuva de sementes e regeneração natural sob três espécies arbóreas em uma floresta em processo de restauração. Revista Brasileira de Botânica, v.29, n.4, p.541-554, 2006.

WANG, B.; SMITH, T. Closing the seed dispersal loop. Trends in Ecology and Evolution, v.17, n.8, p.379-386, 2002.

ZAVATINI, J.A. Dinâmica climática no Mato Grosso do Sul. Geografia, v. 17, n.2, p.65-91, 1992. 